\title{
THE EFECT OF IMPLEMENTATION OF ACCOUNTING INFORMATION SYSTEM AND CONTROL ENVIRONTMENT ON THE EFFECTIVENESS OF INTERNAL CONTROL OF SALES AT CV. KURNIA AGUNG (CASE STUDY AT CV. KURNIA AGUNG REGIONAL JAWA BARAT)
}

\author{
Rosi Mika Aditya Mustopa, Indah Umiyati, Trisandi Eka Putri \\ Sekolah Tinggi Ilmu Ekonomi Sutaatmadja
}

\begin{tabular}{|c|c|}
\hline INFO ARTIKEL & ABSTRAKIABSTRACT \\
\hline $\begin{array}{l}\text { Histori Artikel : } \\
\text { Tgl. Masuk : } 21 \text { Mei } 2019 \\
\text { Tgl. Diterima : } 14 \text { Juni } 2019 \\
\text { Tersedia Online : } 29 \text { Juni } \\
2019 \\
\text { Keywords: } \\
\text { Accounting information } \\
\text { system, control } \\
\text { environment, and } \\
\text { effectiveness of sales } \\
\text { internal control }\end{array}$ & $\begin{array}{l}\text { The purpose of this study to determine the effect } \\
\text { of the implementation of accounting information } \\
\text { systems and control environment to the effectiveness of } \\
\text { internal control sales on the CV. Kurnia Agung. } \\
\text { In this study was prepared using quantitative } \\
\text { research methods, while the data analysis techniques } \\
\text { in this study using descriptive data analysis } \\
\text { techniques. Population and sample in this research is } \\
\text { all employee CV. Kurnia Agung with } 65 \text { respondents } \\
\text { with sample selection technique using purposive } \\
\text { sampling method. The data used are primary data } \\
\text { obtained directly from all employees CV. Kurnia } \\
\text { Agung by distributing questionnaires. Data were } \\
\text { analyzed using multiple linier regression method and } \\
\text { hypothesis test with the help of using Statistical } \\
\text { Program for Society Science (SPSS) V. } 21 \text {. } \\
\text { Based on the results of hypothesis testing in this study } \\
\text { is the accounting information system affect the } \\
\text { effectiveness of internal control sales, control } \\
\text { environment affect the effectiveness of internal control } \\
\text { sales, and accounting information systems and control } \\
\text { environment simultaneously affect the effectiveness of } \\
\text { internal control sales }\end{array}$ \\
\hline
\end{tabular}

\section{PENDAHULUAN}

Sehubungan dengan perkembangan
dunia usaha baik sektor industri,
perdagangan maupun jasa, membuat
persaingan usaha semakin ketat. Setiap
perusahaan selalu berusaha menciptakan
hubungan bisnis yang baik antar
perusahaan. Hal ini merupakan tuntutan
bagi seluruh perusahaan dalam
perkembangan bisnis. Dengan adanya
perkembangan yang semakin pesat ini
ditandai dengan meningkatnya kegiatan
perusahaan dan semakin meningkatnya
kebutuhan dalam pengelolaan keuangan,

sumber daya manusia maupun aspek perencanaan serta pengendalian internal perusahaan. Oleh karena itu, perusahaan harus memiliki pengendalian internal yang sangat efektif dalam menjalankan proses bisnis perusahaan karena pengendalian internal merupakan peranan penting dalam perusahaan untuk mencapai tujuan yang diinginkan. Dalam hal ini, Pimpinan perusahaan bertanggung jawab penuh atas pengendalian internal perusahaan. Pengendalian internal perusahaan berfungsi untuk memberikan informasi yang akurat dan tepat bagi perusahaan dan berguna untuk menjaga asset yang dimiliki 
perusahaan, memeriksa kebenaran dan ketelitian data akuntansi setra meningkatkan efisiensi dalam operasi dan membatu manajer agar tidak ada penyimpangan kebijkan manajemen yang di tetapkan.

Pada umumnya masalah yang sering terjadi dalam pengendalian internal yaitu lemahnya komponen-komponen pengendalian internal perusahaan yang dapat menimbulkan kecurangankecurangan, penyelewengan tugas dan wewenang oleh karyawan perusahaan. Oleh karena itu, lemahnya suatu pengendalian internal akan mengakibatkan proses bisnis dalam perusahaan terhabat. Dalam hal ini pengendalian internal harus ditingkatkan untuk mengurangi tingkat kecurangan yang memungkinkan terjadi.

Penelitian di lakukan pada CV. Kurnia Agung yang merupakan perusahaan yang bergerak di bidang penjualan Book \& Stationary. Masalah yang sering timbul yaitu terdapat dari penjualan. Karena perusahaan ini bergerak di bidang perdagangan yakni penjualan barang ritel maupun grosir. Perusahaan ini telah menerapkan dua sistem yaitu sistem Point Of Sales (POS) dan sistem AKUR/KALAM. Sistem yang digunakan ini bersifat online yang terhubung langsung ke kantor pusat untuk memudahkan pengendalian perusahaannya. Dalam kegiatan penjualan grosiran perusahaan menjadi pemasok untuk toko-toko kecil atau fotocopy dengan sistem pembayaran kredit atau tempo. Perusahaan ini menggunakan sistem akuntansi berupa Point Of Sales (POS) untuk penjualan tunai sedangkan sistem akuntansi yang digunakan untuk proses penjualan kredit berupa sistem aplikasi AKUR/KALAM yang di buat oleh perusahaan itu sendiri. Masalah ini timbul karena kurang ketelitian dalam proses transaksi penjualan baik dalam hal penjualan tunai maupun penjualan kredit yang biasanya terjadi pada kesalahan user dalam menginput suatu jumlah barang atau kesalahan dalam menginput kode barang yang terdapat di dalam transaksi penjualan, yang akan mengakibatkan adanya selisih pencatatan antara fisik barang dengan stock akhir yang ada di aplikasi Akur/Kalam pada saat stock opname di akhir periode. Kemungkinan laporan hasil dari stock ofname akan tidak akurat karena kesalahan-kesalahan yang terjadi. Dalam hal ini, diperlukan adanya sistem informasi akuntansi yang baik dan lingkungan pengendalian untuk mendukung efektivitas pengendalian internal penjualannya.

Dalam mewujudkan pengelolaan aktivitas-aktivitas perusahaan dibutuhkan adanya pengendalian internal yang dapat memberikan informasi yang akurat dan tepat. Dalam hal ini, Pimpinan perusahaan bertanggung jawab atas pengendalian internal perusahaan. Tidak menutup kemungkinan bahwa penerapan pengendalian internal tidak dapat mencegah pemborosan atau penyelewengan paling tidak dapat meminimalisasi pemborosan dan penyelewengan. Dalam hal ini upaya agar efektivitas pengendalian internal baik yaitu dengan menggunakan Sistem informasi akuntansi. Karena sistem informasi akuntansi yang tepat dapat memberikan informasi yang akurat dan jika sistem informasi akuntansi itu sendiri lemah maka proses bisnis akan berjalan dengan tidak baik dikarenakan adanya kesalahankesalahan yang kemungkinan terjadi. Berdasarkan latar belakang di atas peneliti tertarik untuk meneliti tentang pengaruh sistem informasi akuntansi dan lingkungan pengendalian terhadap efektivitas pengendalian internal dan peneliti memilih CV. Kurnia Agung sebagai objek penelitiannya. Maka peneliti akan melakukan penelitian dengan judul "PENGARUH IMPLEMENTASI SISTEM INFORMASI AKUNTANSI DAN LINGKUNGAN PENGENDALIAN TERHADAP EFEKTIVITAS PENGENDALIAN INTERNAL PENJUALAN PADA CV. 
KURNIA AGUNG (Studi Kasus CV. Kurnia Agung Wilayah Jawa Barat)" dengan tujuan untuk mengetahui pengaruh implementasi sistem informasi akuntansi dan lingkungan pengendalian terhadap efektivitas pengendalian internal penjualan pada CV.Kurnia Agung Wilayah Jawa Barat.

Untuk itu hipotesis dalam penelitian ini adalah (1)Sistem informasi akuntansi berpengaruh terhadap efektivitas pengendalian internal penjualan, (2) Lingkungan pengendalian berpengaruh terhadap efektivitas pengendalian internal penjualan, (3) Sistem Informasi akuntansi dan lingkungan engendalian berpengaruh secara simultan terhadap efektivitas pengendalian internal penjualan. Untuk menjawab hipotesis tersebut peneliti menggunakan analisis deskriptif dengan sampel 65 responden.

Berdasarkan hasil penelitian sebelumnya menunjukan bahwa sistem informasi akuntansi (X1) mempunyai pengaruh positif dan signifikan terhadap pengendalian internal penjualan (Peni Fibro Rahayu, 2014) kemudian pengaruh lingkungan pengendalian mempunyai pengaruh positif terhadap pengendalian internal (Heny Kurniawati, 2011).

\section{KERANGKA TEORITIS DAN PENGEMBANGAN HIPOTESIS}

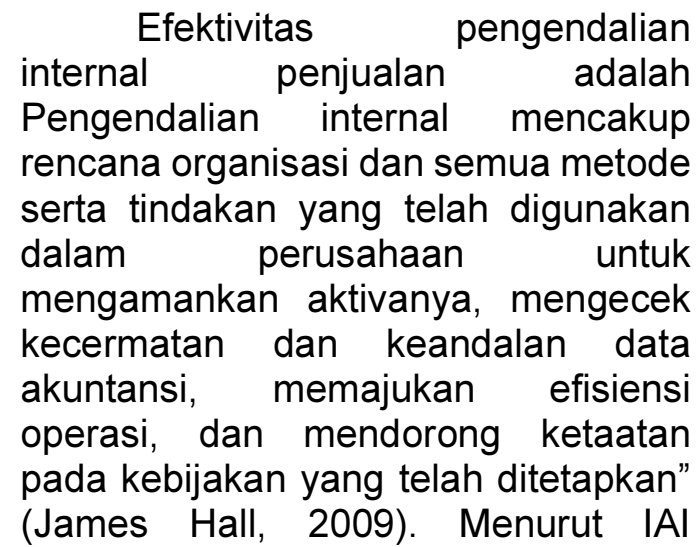

pengendalian internal adalah Pengendalian intern sebagai suatu proses yang dijalankan oleh dewan komisaris,manajemen dan personal lain entitas yang didesain untuk memberikan keyakinan memadai tentang pencapaian 3 (tiga) golongan tujuan berikut ini:

1. Keandalan pelaporan keuangan

2. Efektivitas dan efisiensi operasi

3. Kepatuhan terhadap hukum dan peraturan yang berlaku

Dari penjelasan di atas dapat disimpulkan bahwa efektivitas pengendalian internal penjualan adalah suatu cara atau tindakan perusahaan dalam proses penjualan sehingga penjualan berjalan lancar yang akan menciptkan tercapainya suatu tujuan dan hasil sesuai dengan tujuan yang telah ditetapkan perusahaan sebelumnya.

Menurut Susanto (2008) Sistem informasi akuntansi adalah kumpulan (integritas) dari sub sistem/komponen baik fisik maupun non fisik yang saling berhubungan dan bekerjasama satu sama lain secara harmonis untuk mengolah data transaksi yang berkaitan dengan masalah keuangan menjadi informasi keuangan. Terdapat beberapa unsur dalam sistem informasi akuntansi, yaitu:

1. Sumber daya manusia dan alat Manusia merupakan unsur sistem informasi akuntansi yang berperan di dalam pengambilan keputusan apakah sistem dapat dilaksanakan dengan baik atau tidak, manusia juga akan mengendalikan jalannya sistem. Alat merupakan unsur sistem informasi akuntansi yang berperan di dalam mempercepat pengolahan data,meningkatkan ketelitian kalkulasi atau perhitungan dan meningkatkan kerapian bentuk organisasi.

2. Catatan 
Data yang dihasilkan dari catatan-catatan berupa jurnaljurnal, buku besar, dan buku tambahan. Data juga dihasilkan dari formulir-formulir yang digunakan sebagai bukti tertulis dari transaksi.

3. Informasi atau laporan-laporan

Hasil akhir dari sistem informasi akuntansi adalah informasi akuntansi keuangan dan informasi akuntansi manajemen. Informasi tersebut dapat berupa laporan neraca, laporan laba rugi, laporan perubahan modal, laporan arus kas, laporan laba ditahan, laporan harga pokok penjualan, daftar saldo persediaan, dan sebagainya.

Menurut Guy et al (2002) menjelaskan lingkungan pengendalian menentukan kualitas entitas dengan mempengaruhi kesadaran akan pengendalian dari orang-orang sekitarnya. Lingkungan pengendalian ini terdiri dari 7 (tujuh) faktor yaitu :

1. Integritas dan nilai-nilai etika

2. Komitmen terhadap kompetensi

3. Partisipasi Dewan Direksi dan Komite Audit

4. Gaya operasi dan filosofi manajemen

5. Struktur Organisasi

6. Pendelegasian wewenang dan tanggung jawab

7. Kebijakan dan praktek sumber daya manusia dan aplikasinya

\section{Pengaruh Sistem Informasi Akuntansi Terhadap Efektivitas Pengendalian Internal Penjualan}

Setiap perusahaan yang bergerak dibidang perdagangan kegiatan utama yang dilakukannya yaitu penjualan. Penjualan merupakan pendapatan perusahaan yang akan berpengaruh terhadap laba perusahaan. Agar laba perusahaan dapat meningkat setiap periodenya maka perlu adanya sistem informasi akuntansi. Dengan adanya sistem informasi akuntansi ini proses penjualan akan berjalan lebih baik tanpa ada kecurangan-kecurangan pihak eksternal maupun internal dan guna untuk mendukung pengendalian internal mengenai tanggung jawab dan perlindungan harta perusahaan. Dalam penelitian Peni Fibro Rahayu (2014) menunjukan hasil bahwa sistem informasi akuntansi berpengaruh positif terhadap dan signifikan terhadap pengendalian internal penjualan. Kemudian Susi Rahmawati (2013) mengatakan bahwa sistem informasi akuntansi penjualan telah berpengaruh signifikan terhadap efektivitas pengendalian internal. Oleh karena itu, hipotesis berikut dibuat untuk menentukan pengaruh sistem informasi akuntansi terhadap efektivitas pengendalian internal penjualan:

$\mathrm{H} 1$ : Sistem Informasi Akuntansi Berpengaruh Terhadap Efektivitas Pengendalian Internal Penjualan

Pengaruh Lingkungan
Pengendalian Terhadap Efektivitas
Pengendalian Internal Penjualan
Komponen lingkungan
pengendalian (control environment)
merupakan fondasi bagi komponen
lainnya (penilaian risiko, aktivitas
pengendalian, informasi dan
komunikasi, monitoring) yang menyediakan disiplin dan struktur. Sehingga komponen lingkungan pengendalian merupakan dasar bagi pembentukan komponen pengendalian intern lainnya. Pada dasarnya suatu perusahaan sangat memerlukan adanya lingkungan pengendalian yang baik untuk menjalankan proses bisnis perusahaan. Kesimpulannya bahwa lingkungan pengendalian merupakan dasar bagi pembentukan suatu 
pengendalian internal dalam suatu perusahaan. Dalam penelitian Guy et al (2002) menjelaskan bahwa "Lingkungan pengendalian merupakan pondasi kedisiplinan dan struktur dari semua komponen pengendalian internal lainnya." Sehingga dapat disimpulkan bahwa kehandalan sistem pengendalian intern sangat dipengaruhi oleh unsur-unsur lingkungan pengendalian. Oleh karena itu, hipotesis berikut dibuat untuk menentukan pengaruh lingkungan pengendalian internal terhadap efektivitas pengendalian internal penjualan:

$\mathrm{H} 2$ : Lingkungan Pengendalian Berpengaruh Terhadap Efektivitas Pengendalian Internal Penjualan

\section{Pengaruh Sistem Informasi Akuntansi Dan Lingkungan Pengendalian Terhadap Efektivitas Pengendalian Internal Penjualan}

Dalam memperlancar proses bisnis suatu perusahaan dalam mencapai suatu tujuan, perusahaan harus menggunakan beberapa cara untuk meningkatkan efektivitas pengendalian internal perusahaan. Karena pengendalian internal sangat menunjang dalam kegiatan penjualan perusahaan untuk mendapatkan laba yang di harapkan. Beberapa cara tersebut yaitu: Pertama, dengan menggunakan suatu sistem informasi akuntansi yang dapat memberikan informasi yang cepat, tepat dan akurat kepada pengguna informasi sebagai dasar pengambilan keputusan pihak manajemen. Kedua, perusahaan juga harus memperhatikan lingkungan pengendalian yang ada di perusahaan karena lingkungan pengendalian sebagai dasar pembentukan pengendalian internal di perusahaan. Oleh karena itu, hipotesis berikut dibuat untuk menentukan pengaruh sistem informasi akuntansi dan lingkungan pengendalian terhadap efektivitas pengendalian internal penjualan:

H3 : Sistem Informasi Akuntansi Dan Lingkungan

Pengendalian Berpengaruh Secara Simultan Terhadap Efektivitas Pengendalian Internal Penjualan.

\section{METODOLOGI PENELITIAN}

$$
\text { Teknik Nonprobabbility }
$$

sampling yang digunakan dalam pengambilan sample pada penelitian ini adalah metode Purposive sampling. Sampel dalam penelitian ini adalah End user, khususnya karyawan bagian Teller dan Customer service. Jumlah sampel yang di ambil dalam penelitian ini adalah sebanyak 42 karyawan dari 15 Bank BJB di kota Subang. Dalam penelitian ini populasi yang digunakan adalah para end user, khususnya pada karyawan bagian teller dan customer service yang telah bekerja menggunakan software akuntansi, nama Sistem Informasi Akuntansi yang di gunakan dibank BJB adalah BJB Fast dan EBA. Populasi dari penelitian ini yaitu para kayawan bagian teller dan customer service di Bank BJB kota Subang. Teknik pengumpulan data yang digunakan adalah teknik wawancara dan kuesioner.

\section{HASIL PENELITIAN}


Penelitian ini merupakan penelitian survei yang termasuk dalam metode kuantitatif. Metode penelitian kuantitatif adalah metode penelitian yang digunakan untuk meneliti populasi atau sempel tertentu dengan tujuan untuk menguji hipotesis yang telah di tetapkan. Metode ini berlandasan pada filsafat positivisme, menggunakan instrumen penelitian untuk pengumpulan data, dan analisis data bersifat kuantitatif/statistik (Sugiyono, 2016). Jenis data yang digunakan dalam penelitian ini merupakan data primer. Data primer adalah data yang diperoleh dari sumber data pertama dilokasi penelitian atau objek penelitian (Burhan, 2011). yang digunakan dalam penelitian ini merupakan data primer. Data primer adalah data yang diperoleh dari sumber data pertama dilokasi penelitian atau objek penelitian (Burhan, 2011).

Dalam penelitian ini pengumpulan data yang dilakukan berdasarkan teknik kuesioner dan observasi. Daftar pertanyaan/pernyataan kuesioner dalam penelitian ini terdiri dari dua bagian. Pertama, bagian umum mengenai identitas responden yang terdiri dari 5 (buah) pertanyaan yang terdiri dari jenis kelamin, umur, pendidikan terakhir, lama bekerja, jabatan. Kedua, berisis tentang pernyataan yang berisi tentang variabel yang diteliti. Responden diminta untuk memilih jawaban dalam bentuk skala ordinal yang berisi lima tingkat jawaban yang diberi skor sebagai berikut:

Skor 1 : Sangat Tidak Setuju (STS)

Skor 2 : Tidak Setuju (TS)

Skor 3 : Ragu-Ragu (RR)

Skor 4 : Setuju (S)

Skor 5 : Sangat Setuju (SS)

Sebelum kuesioner penelitian disebarkan kepada responden sesungguhnya, kuesioner ini harus diuji kualitasnya terlebih dahulu. Hal ini dilakukan karena benar tidaknya sebuah data sangat menentukan bermutu atau tidaknya hasil penelitian. Benar tidaknya sebuah data tergantung pada instrumen penelitian yang digunakan. Instrumen penelitian harus memenuhi syarat valid dan reliabel. Dalam penelitian ini uji validitas instrumen dan reliabilitas dilakukan pada 30 responden diluar sampel yang sudah di tetapkan, kemudian data yang terkumpul dianalisis menggunakan program SPSS.

\section{Tabel 1: Hasil Uji Validitas Butir Instrumen untuk Sistem Informasi Akuntansi}

\begin{tabular}{|l|l|l|l|}
\hline Pernyataan & r Hitung & r Tabel & Ket \\
\hline Pernyataan 1,221 &, 306 & $\begin{array}{l}\text { Tidak } \\
\text { Valid }\end{array}$ \\
\hline Pernyataan 2 & 702 &, 306 & valid \\
\hline Pernyataan 3,513 &, 306 & Valid \\
\hline Pernyataan 4,562 &, 306 & Valid \\
\hline Pernyataan 5,,827 &, 306 & Valid \\
\hline Pernyataan 6 &, 276 &, 306 & $\begin{array}{l}\text { Tidak } \\
\text { Valid }\end{array}$ \\
\hline $\begin{array}{l}\text { Pernyataan 7 } \\
\text { Pernyataan 8,777 }\end{array}$ &, 306 & Valid \\
\hline $\begin{array}{l}\text { Pernyataan 9,718 } \\
\text { Pernyataan } \\
10\end{array}$ &, 360 &, 306 & Valid \\
\hline $\begin{array}{l}\text { Pernyataan } \\
11\end{array}$ &, 640 & Valid \\
\hline $\begin{array}{l}\text { Pernyataan } \\
12\end{array}$ &, 795 &, 306 & Valid \\
\hline $\begin{array}{l}\text { Pernyataan } \\
13\end{array}$ &, 787 & Valid \\
\hline $\begin{array}{l}\text { Pernyataan } \\
14\end{array}$ &, 796 &, 306 & Valid \\
\hline
\end{tabular}

Sumber: Data yang diolah (2018) 
Tabel 2: Hasil Uji Validitas Butir Instrumen untuk Lingkungan Pengendalian

\begin{tabular}{|l|l|l|l|}
\hline Pernyataan & \multicolumn{1}{|l}{ Hitung } & Tabel & Ket \\
\hline $\begin{array}{l}\text { Pernyataan } \\
1\end{array}$ &, 800 &, 306 & Valid \\
\hline $\begin{array}{l}\text { Pernyataan } \\
2\end{array}$ &, 648 &, 306 & Valid \\
\hline $\begin{array}{l}\text { Pernyataan } \\
3\end{array}$ &, 801 &, 306 & Valid \\
\hline $\begin{array}{l}\text { Pernyataan } \\
4\end{array}$ &, 773 &, 306 & Valid \\
\hline $\begin{array}{l}\text { Pernyataan } \\
5\end{array}$ &, 790 &, 306 & Valid \\
\hline $\begin{array}{l}\text { Pernyataan } \\
6\end{array}$ &, 576 &, 306 & Valid \\
\hline $\begin{array}{l}\text { Pernyataan } \\
7\end{array}$ &, 676 &, 306 & Valid \\
\hline $\begin{array}{l}\text { Pernyataan } \\
8\end{array}$ &, 649 &, 306 & Valid \\
\hline $\begin{array}{l}\text { Pernyataan } \\
9\end{array}$ &, 640 &, 306 & Valid \\
\hline $\begin{array}{l}\text { Pernyataan } \\
10\end{array}$ &, 631 &, 306 & Valid \\
\hline $\begin{array}{l}\text { Pernyataan } \\
11\end{array}$ & 458 &, 306 & Valid \\
\hline $\begin{array}{l}\text { Pernyataan } \\
12\end{array}$ &, 670 &, 306 & Valid \\
\hline $\begin{array}{l}\text { Pernyataan } \\
13\end{array}$ &, 626 &, 306 & Valid \\
\hline $\begin{array}{l}\text { Pernyataan } \\
14\end{array}$ &, 837 &, 306 & Valid \\
\hline $\begin{array}{l}\text { Pernyataan } \\
17\end{array}$ &, 596 &, 306 & Valid \\
\hline
\end{tabular}
(2018)

Tabel 3: Hasil Uji Validitas Butir Instrumen untuk Efektivitas Pengendalian Internal Penjualan

\begin{tabular}{|l|l|l|l|}
\hline Pernyataan & \multicolumn{1}{|l|}{ Hitung } & $\mathbf{r}$ & Ket \\
\hline Tabel & \\
\hline Pernyataan 1 &, 155 &, 306 & $\begin{array}{l}\text { Tidak } \\
\text { Valid }\end{array}$ \\
\hline Pernyataan 2 &, 101 &, 306 & $\begin{array}{l}\text { Tidak } \\
\text { Valid }\end{array}$ \\
\hline Pernyataan 3 &, 602 &, 306 & Valid \\
\hline Pernyataan 4 &, 737 &, 306 & Valid \\
\hline Pernyataan 6 &, 731 &, 306 & Valid \\
\hline Pernyataan 7 &, 713 &, 306 & Valid \\
\hline Pernyataan 8 &, 790 &, 306 & Valid \\
\hline Pernyataan 9 &, 791 &, 306 & Valid \\
\hline $\begin{array}{l}\text { Pernyataan } \\
10\end{array}$ &, 846 &, 306 & Valid \\
\hline $\begin{array}{l}\text { Pernyataan } \\
11\end{array}$ &, 749 &, 306 & Valid \\
\hline $\begin{array}{l}\text { Pernyataan } \\
12\end{array}$ &, 739 &, 306 & Valid \\
\hline $\begin{array}{l}\text { Pernyataan } \\
13\end{array}$ &, 722 &, 306 & Valid \\
\hline Pernyataan &, 765 & Valid \\
\hline
\end{tabular}

Sumber: Data yang diolah (2018)

Dari hasil analisis data di atas, menunjukan bahwa hasil dari uji validitas butir instrumen penelitian ini ada yang valid dan ada yang tidak valid. Karena adanya hasil yang tidak valid, peneliti melakukan perbaikan pernyataan dalam kuesioner agar mampu mengungkapkan sesuatu yang akan di ukur, sehingga kuesioner tersebut dapat digunakan sebagai instrumen penelitian.

Tabel 4 : Data Reliabilitas

\begin{tabular}{|l|l|l|}
\hline Variabel & $\begin{array}{l}\text { Croncbach' Keteranga } \\
\text { s Alpha }\end{array}$ \\
\hline
\end{tabular}




\begin{tabular}{|l|l|l|}
\hline $\begin{array}{l}\text { Sistem } \\
\text { Informasi } \\
\text { Akuntansi }\end{array}$ & $0,923>0,60$ & Reliabel \\
\hline $\begin{array}{l}\text { Lingkungan } \\
\text { Pengendalia }\end{array}$ & $0,935>0,60$ & Reliabel \\
n & & \\
\hline $\begin{array}{l}\text { Efektivitas } \\
\text { Pengendalia } \\
n \begin{array}{l}\text { Internal } \\
\text { Penjualan }\end{array}\end{array}$ & & \\
\hline
\end{tabular}

Sumber: Data yang diolah (2018)

Populasi dari penelitian ini merupakan seluruh karyawan dari CV.Kurnia Agung. Kemudian sampel dari penelitian ini sebanyak 65 responden. Penelitian ini menggunakan teknik Nonprobability sampling dengan metode sampling yang digunakan adalah Purposive Sampling.

\section{HASIL PENELITIAN}

Sampel data yang diperoleh memiliki beberapa karakteristik berdasarkan jenis kelamin, umur, pendidikan terakhir, lama bekerja, jabatan yang sebagaimana disajikan pada tabel 5 .

Tabel 5 : Karakteristik Responden

\begin{tabular}{|c|c|c|c|}
\hline klasifika & akarakteristi & iFre & Perce \\
\hline si & k & $c y$ & nt \\
\hline Jenis & Laki-laki & 37 & $57 \%$ \\
\hline $\begin{array}{l}\text { Kelamai } \\
\mathrm{n}\end{array}$ & Perempuan & 28 & $43 \%$ \\
\hline Umur & $<20$ Tahun & 10 & $15 \%$ \\
\hline & $\begin{array}{l}20-25 \\
\text { Tahun }\end{array}$ & 49 & $76 \%$ \\
\hline & \begin{tabular}{|l|}
$26-30$ \\
Tahun
\end{tabular} & 6 & $9 \%$ \\
\hline $\begin{array}{l}\text { Pendidik } \\
\text { an }\end{array}$ & $\begin{array}{l}\text { SMA/Seder } \\
\text { ajat }\end{array}$ & 65 & $100 \%$ \\
\hline Terakhir & Diploma & 0 & 0 \\
\hline & Sarjana & 0 & 0 \\
\hline Lama & $<1$ Tahun & 6 & $9,2 \%$ \\
\hline Bekerja & 1-3 Tahun & 29 & $\begin{array}{l}44,6 \\
\%\end{array}$ \\
\hline & 4-6 Tanun & 15 & $\begin{array}{l}23,1 \\
\%\end{array}$ \\
\hline
\end{tabular}

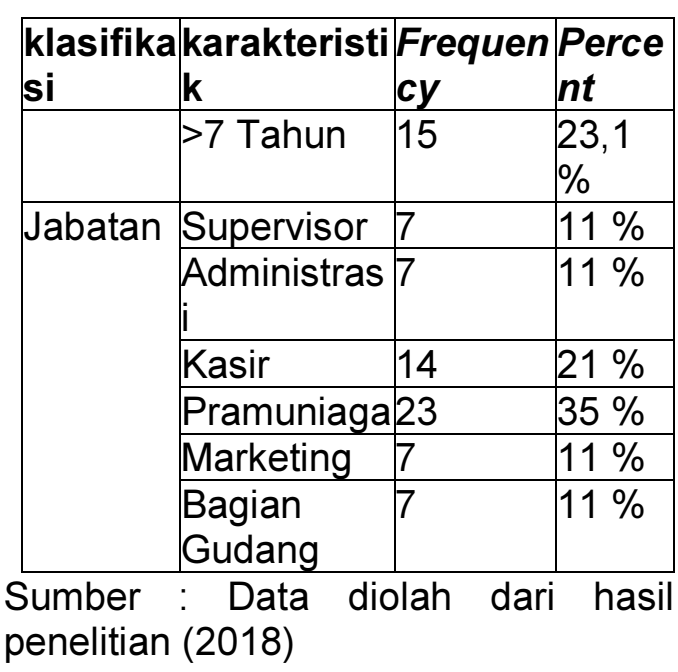

Selanjutnya dalam penelitian ini dilakukan uji statistik deskriptif yang akan bertujuan untuk mengetahui nilai minimum nilai maksimum, niali mean dan standar deviasi pada setiap variabel. Berikut ini adalah hasil uji statistik deskriptif yang diolah menggunakan SPSS:

\section{Tabel 6: Hasil Uji Statistik Deskriptif Descriptive Statistics}

\begin{tabular}{|c|c|c|c|c|}
\hline & $\mathrm{N}$ & $\begin{array}{l}\text { Minimu } \\
\mathrm{m}\end{array}$ & $\begin{array}{l}\text { Maximu } \\
\mathrm{m}\end{array}$ & Mea \\
\hline & Statistic & Statistic & Statistic & Stati \\
\hline $\begin{array}{ll}\text { SIA } & \\
\text { LP } & \\
\text { EP } & \\
\text { Valid } & \mathrm{N} \\
\text { (listwise) } & \end{array}$ & $\begin{array}{l}65 \\
65 \\
65 \\
65\end{array}$ & $\begin{array}{l}3,57 \\
3,71 \\
3,50\end{array}$ & $\begin{array}{l}5,00 \\
5,00 \\
4,93\end{array}$ & $\begin{array}{l}4,3 \\
4,3 \\
4,3\end{array}$ \\
\hline
\end{tabular}

Pada penelitian ini dilakukan uji validitas suatu variabel terhadap suatu pernyataan. Hasil uji validitas untuk kuesioner independensi dengan $\mathrm{dk}$ atau $\mathrm{df}=65-2=63$ pada tingkat signifikansi (a) $5 \%$ atau 0,05 diperoleh $r_{\text {tabel }}=0,2058$ bahwa nilai item-item kuesioner memilii nilai rhitung yang positif dan rhitung $>r_{\text {tabel }}$ sebagai kriteria 
yang ditetapkan. Hasil pengujian validitas menunjukan bahwa item pernyataan dari semua variabel dinyatakan sudah valid, karena memiliki $r_{\text {hitung }}$ positif dan dan rhitung $>$ $r_{\text {tabel. Dapat dilihat pada tabel di bawah }}$ ini:

\section{Tabel 7: Hasil Validitas Data}

\begin{tabular}{|c|c|c|c|}
\hline Variabel & rhitun & rtabe & $\begin{array}{l}\text { Keteranga } \\
n\end{array}$ \\
\hline \multicolumn{4}{|l|}{ Variabel $X_{1}$} \\
\hline $\begin{array}{l}\text { Sistem } \\
\text { Informasi } \\
\text { Akuntansi } 1\end{array}$ & 259 & $\begin{array}{l}, 20 \\
6\end{array}$ & Valid \\
\hline \begin{tabular}{|l} 
Sistem \\
Informasi \\
Akuntansi 2
\end{tabular} & 471 & $\begin{array}{l}20 \\
6\end{array}$ & Valid \\
\hline $\begin{array}{l}\text { Sistem } \\
\text { Informasi } \\
\text { Akuntansi } 3\end{array}$ & 321 & $\begin{array}{l}, 20 \\
6\end{array}$ & Valid \\
\hline $\begin{array}{l}\text { Sistem } \\
\text { Informasi } \\
\text { Akuntansi } 4\end{array}$ & 261 & $\begin{array}{l}20 \\
6\end{array}$ & Valid \\
\hline $\begin{array}{l}\text { Sistem } \\
\text { Informasi } \\
\text { Akuntansi } 5\end{array}$ & 450 & $\begin{array}{l}, 20 \\
6\end{array}$ & Valid \\
\hline $\begin{array}{l}\text { Sistem } \\
\text { Informasi } \\
\text { Akuntansi } 6\end{array}$ & 444 & $\begin{array}{l}20 \\
6\end{array}$ & Valid \\
\hline $\begin{array}{l}\text { Sistem } \\
\text { Informasi } \\
\text { Akuntansi } 7\end{array}$ & 428 & $\begin{array}{l}, 20 \\
6\end{array}$ & Valid \\
\hline $\begin{array}{l}\text { Sistem } \\
\text { Informasi } \\
\text { Akuntansi } 8\end{array}$ & 493 & $\begin{array}{l}, 20 \\
6\end{array}$ & Valid \\
\hline $\begin{array}{l}\text { Sistem } \\
\text { Informasi } \\
\text { Akuntansi } 9\end{array}$ & 484 & $\begin{array}{l}, 20 \\
6\end{array}$ & Valid \\
\hline $\begin{array}{l}\text { Sistem } \\
\text { Informasi } \\
\text { Akuntansi } 10\end{array}$ & 365 & $\begin{array}{l}, 20 \\
6\end{array}$ & Valid \\
\hline $\begin{array}{l}\text { Sistem } \\
\text { Informasi } \\
\text { Akuntansi } 11 \\
\end{array}$ & 353 & $\begin{array}{l}, 20 \\
6\end{array}$ & Valid \\
\hline \begin{tabular}{|l|} 
Sistem \\
Informasi \\
Akuntansi 12
\end{tabular} &, 505 & $\begin{array}{l}, 20 \\
6\end{array}$ & Valid \\
\hline
\end{tabular}

\begin{tabular}{|c|c|c|c|}
\hline Variabel & $\begin{array}{l}\text { Yhitun } \\
\text { g }\end{array}$ & rtabe & $\begin{array}{l}\text { Keteranga } \\
n\end{array}$ \\
\hline $\begin{array}{l}\text { Sistem } \\
\text { Informasi } \\
\text { Akuntansi } 13\end{array}$ & 359 & $\begin{array}{l}, 20 \\
6\end{array}$ & Valid \\
\hline \begin{tabular}{|l|} 
Sistem \\
Informasi \\
Akuntansi 14
\end{tabular} & 329 & $\begin{array}{l}, 20 \\
6\end{array}$ & Valid \\
\hline Variabel $X_{2}$ & & & \\
\hline $\begin{array}{l}\text { Lingkungan } \\
\text { Pengendalia } \\
\text { n } 1\end{array}$ & 438 & $\begin{array}{l}, 20 \\
6\end{array}$ & Valid \\
\hline $\begin{array}{l}\text { Lingkungan } \\
\text { Pengendalia } \\
\text { n } 2\end{array}$ & 632 & $\begin{array}{l}, 20 \\
6\end{array}$ & Valid \\
\hline $\begin{array}{l}\text { Lingkungan } \\
\text { Pengendalia } \\
\text { n } 3\end{array}$ &, 543 & $\begin{array}{l}, 20 \\
6\end{array}$ & Valid \\
\hline $\begin{array}{l}\text { Lingkungan } \\
\text { Pengendalia } \\
\text { n } 4\end{array}$ & ,388 & $\begin{array}{l}, 20 \\
6\end{array}$ & Valid \\
\hline $\begin{array}{l}\text { Lingkungan } \\
\text { Pengendalia } \\
\text { n } 5\end{array}$ &, 365 & $\begin{array}{l}, 20 \\
6\end{array}$ & Valid \\
\hline $\begin{array}{l}\text { Lingkungan } \\
\text { Pengendalia } \\
\text { n } 6\end{array}$ & 487 & $\begin{array}{l}, 20 \\
6\end{array}$ & Valid \\
\hline $\begin{array}{l}\text { Lingkungan } \\
\text { Pengendalia } \\
\text { n } 7\end{array}$ & ,232 & $\begin{array}{l}, 20 \\
6\end{array}$ & Valid \\
\hline $\begin{array}{l}\text { Lingkungan } \\
\text { Pengendalia } \\
\text { n } 8\end{array}$ & 485 & $\begin{array}{l}, 20 \\
6\end{array}$ & Valid \\
\hline $\begin{array}{l}\text { Lingkungan } \\
\text { Pengendalia } \\
\text { n } 9\end{array}$ &, 558 & $\begin{array}{l}, 20 \\
6\end{array}$ & Valid \\
\hline $\begin{array}{l}\text { Lingkungan } \\
\text { Pengendalia } \\
\text { n } 10 \\
\end{array}$ &, 334 & $\begin{array}{l}, 20 \\
6\end{array}$ & Valid \\
\hline $\begin{array}{l}\text { Lingkungan } \\
\text { Pengendalia } \\
\text { n } 11\end{array}$ & ,375 & $\begin{array}{l}, 20 \\
6\end{array}$ & Valid \\
\hline $\begin{array}{l}\text { Lingkungan } \\
\text { Pengendalia } \\
\text { n } 12 \\
\end{array}$ & ,375 & $\begin{array}{l}, 20 \\
6\end{array}$ & Valid \\
\hline $\begin{array}{l}\text { Lingkungan } \\
\text { Pengendalia } \\
\text { n } 13\end{array}$ & ,354 & $\begin{array}{l}, 20 \\
6\end{array}$ & Valid \\
\hline
\end{tabular}




\begin{tabular}{|c|c|c|c|}
\hline Variabel & $\begin{array}{l}\text { Yhitun } \\
g\end{array}$ & rtabe & $\begin{array}{l}\text { Keteranga } \\
\text { n }\end{array}$ \\
\hline $\begin{array}{l}\text { Lingkungan } \\
\text { Pengendalia } \\
\text { n } 14\end{array}$ &, 564 & $\begin{array}{l}, 20 \\
6\end{array}$ & Valid \\
\hline $\begin{array}{l}\text { Lingkungan } \\
\text { Pengendalia } \\
\text { n } 15\end{array}$ & 305 & $\begin{array}{l}, 20 \\
6\end{array}$ & Valid \\
\hline $\begin{array}{l}\text { Lingkungan } \\
\text { Pengendalia } \\
\text { n } 16 \\
\end{array}$ &, 359 & $\begin{array}{l}, 20 \\
6\end{array}$ & Valid \\
\hline $\begin{array}{l}\text { Lingkungan } \\
\text { Pengendalia } \\
\text { n } 17\end{array}$ & 435 & $\begin{array}{l}, 20 \\
6\end{array}$ & Valid \\
\hline Variabel Y & & & \\
\hline \begin{tabular}{|l|} 
Efektivitas \\
Pengendalia \\
n Internal \\
Penjualan 1 \\
\end{tabular} & 469 & $\begin{array}{l}, 20 \\
6\end{array}$ & Valid \\
\hline \begin{tabular}{|l|} 
Efektivitas \\
Pengendalia \\
n Internal \\
Penjualan 2
\end{tabular} & ,455 & $\begin{array}{l}, 20 \\
6\end{array}$ & Valid \\
\hline \begin{tabular}{|l|} 
Efektivitas \\
Pengendalia \\
n Internal \\
Penjualan 3 \\
\end{tabular} & ,397 & $\begin{array}{l}, 20 \\
6\end{array}$ & Valid \\
\hline $\begin{array}{l}\text { Efektivitas } \\
\text { Pengendalia } \\
n \quad \text { Internal } \\
\text { Penjualan } 4\end{array}$ & 293 & $\begin{array}{l}, 20 \\
6\end{array}$ & Valid \\
\hline \begin{tabular}{|l|} 
Efektivitas \\
Pengendalia \\
n Internal \\
Penjualan 5
\end{tabular} &, 494 & $\begin{array}{l}, 20 \\
6\end{array}$ & Valid \\
\hline $\begin{array}{l}\text { Efektivitas } \\
\text { Pengendalia } \\
\text { n Internal } \\
\text { Penjualan } 6 \\
\end{array}$ & 375 & $\begin{array}{l}, 20 \\
6\end{array}$ & Valid \\
\hline \begin{tabular}{|l|} 
Efektivitas \\
Pengendalia \\
n Internal \\
Penjualan 7 \\
\end{tabular} &, 302 & $\begin{array}{l}, 20 \\
6\end{array}$ & Valid \\
\hline \begin{tabular}{|l|} 
Efektivitas \\
Pengendalia \\
n Internal \\
Penjualan 8
\end{tabular} & ,324 & $\begin{array}{l}20 \\
6\end{array}$ & Valid \\
\hline \begin{tabular}{|l|} 
Efektivitas \\
Pengendalia
\end{tabular} & ,292 & $\begin{array}{l}, 20 \\
6\end{array}$ & Valid \\
\hline
\end{tabular}

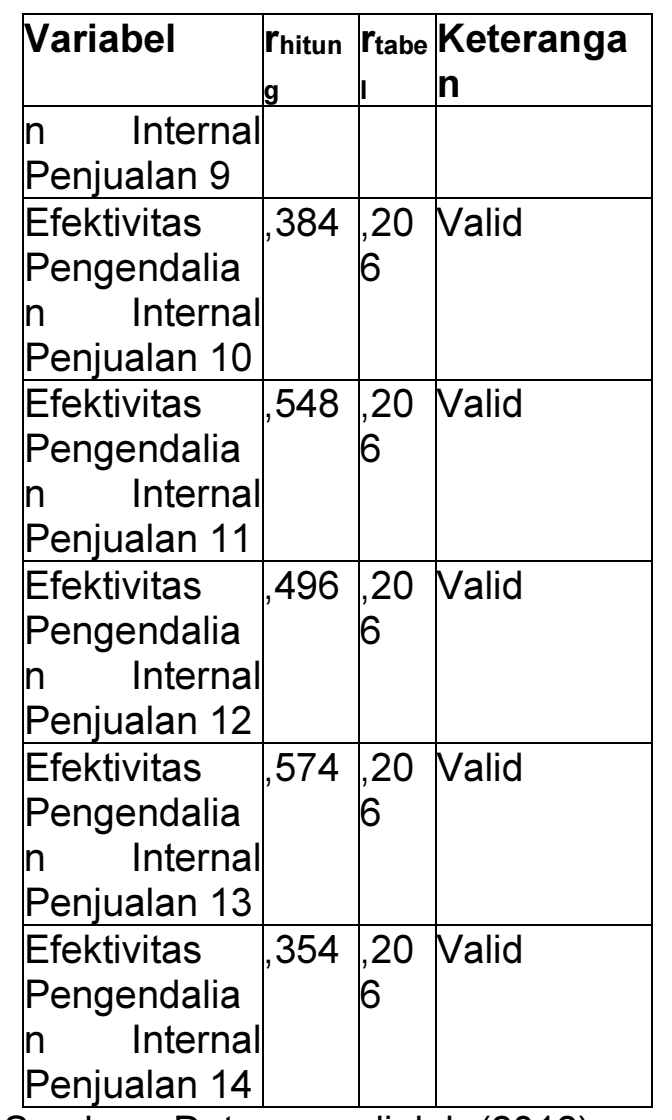

Sumber : Data yang diolah (2018)

Selanjutnya pengujian reliabilitas menunjukan seberapa besar suatu instrumen dapat dipercaya dan digunakan untuk alat pengumpulan data. Hasil pengujian reliabilitas pada penelitian ini sebagai berikut:

Tabel 8: Hasil Reliabilitas Data

\begin{tabular}{|c|c|}
\hline Variabel & \begin{tabular}{l|l} 
Cronba & Ketera \\
ch's & ngan \\
Alpha & \\
\end{tabular} \\
\hline Sistem Informas & i, $774>$ Reliab \\
\hline Akuntansi & 0,60 \\
\hline Lingkungan & $>$ Reliab \\
\hline Pengendalian & 0,60 \\
\hline Efektivitas & $>$ Reliab \\
\hline $\begin{array}{l}\text { Pengendalian } \\
\text { Internal Penjualan }\end{array}$ & 0,60 \\
\hline
\end{tabular}


Berdasarkan tabel di atas menunjukan bahwa hasil uji reliabilitas data pada penelitian ini semua instrumen dari masing-masing variabel adalah reliabel atau dapat di percaya dan dapat digunakan untuk pengumpulan data karena nilai Cronbach's Alpha $>0,60$ yang artinya

\begin{tabular}{|c|c|c|c|}
\hline \multirow{2}{*}{\multicolumn{2}{|c|}{ Model }} & \multicolumn{2}{|c|}{$\begin{array}{l}\text { Collinearity } \\
\text { Statistics }\end{array}$} \\
\hline & & $\begin{array}{l}\text { Toleranc } \\
\mathrm{e}\end{array}$ & VIF \\
\hline 1 & $\begin{array}{l}\text { (Constant } \\
\text { ) } \\
\text { SIA } \\
\text { LP }\end{array}$ & $\begin{array}{l}, 588 \\
, 588\end{array}$ & $\begin{array}{l}1,700 \\
1,700\end{array}$ \\
\hline
\end{tabular}

data yang di pakai pada kuesioner tersebut sudah reliabel dan layak dijadikan alat ukur dalam pengujian statistik.

Dalam penelitian ini selain melakukan uji validitas dan reliabilitas, penelitian ini juga melakukan uji asumsi klasik yaitu uji normalitas, uji multikolinearitas, uji heteroskedasitas. Dalam uji normalitas dapat dilihat dari normal probability plot dengan hasil bahwa titik-titik pada grafik menyebar dan mengikuti garis diagonal, maka dalam hal ini dapat dikatakan data mengikuti pola distribusi normal, dan dapat dilihat pada gambar dibawah ini:

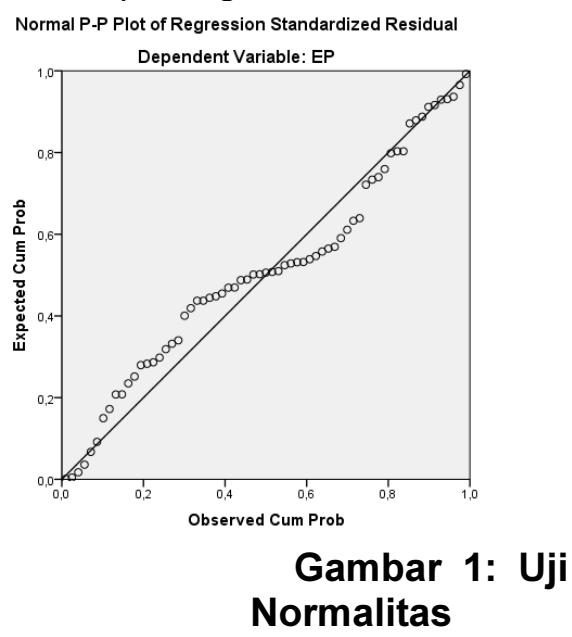

Selanjutnya untuk uji multikolinearitas dapat menunjukan hasil bahwa semua variabel bebas memiliki nilai VIF $<10$ atau nilai Tolerance $>0,1$ maka dapat dikatakan semua variabel yang digunakan tidak terjadi gejala multikolinearitas pada model regresi ini. Dapat dilihat pada tabel dibawah ini:

\section{Tabel 9: Uji Multikolinearitas

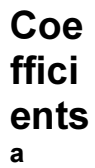

a. Dependent Variabel: Y

Sumber : Data Output SPSS

Kemudian dalam uji heteroskedasitas menunjukan hasil bahwa di dalam diagram scatterplot tidak ada pola tertentu serta titik-titik menyebar diatas dan dibawah angka 0 pada sumbu $Y$ yang dinyatakan bahwa tidak terjadi heteroskedasitas, dapat dilihat pada gambar dibawah ini: 


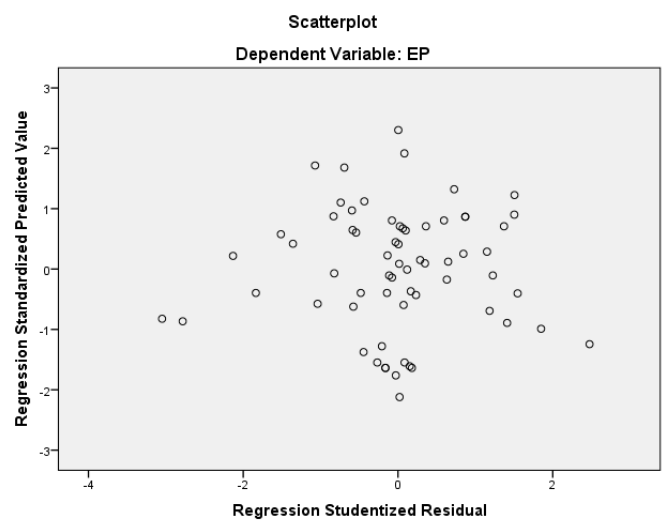

\section{Gambar 2: Hasil Uji Heteroskedasitas}

\section{Sumber: Data Output SPSS}

Pada penelitian ini dalam pengujian hipotesis menggunakan beberapa metode yaitu menggunakan analisis regresi linier berganda, uji statistik t, uji statistik $F$, dan uji koefisien determinasi. Dalam pengujian hipotesis ini peneliti mengolah data menggunakan SPSS. Hasil dari analisis regresi linier berganda menunjukan persamaan sebagai berikut:

$Y=0,794+0,307 X_{1}+0,506 X_{2}$

Persamaan tersebut dapat dilihat dari tabel berikut ini:

Tabel 10: Model Persamaan Regresi Coefficients $^{a}$

Selanjutnya dalam analisis statistik $t$ penelitian ini menunjukan hasil sebagai berikut:

Tabel 11: Hasil Uji Statistik t Coeffisients $^{a}$

\begin{tabular}{|ll|l|l|}
\hline Model & & $\mathrm{t}$ & Sig. \\
\hline \multirow{4}{*}{1} & $\begin{array}{l}\text { (Constan } \\
\text { t) }\end{array}$ & 1,875 &, 066 \\
& SIA & 2,671 &, 010 \\
& LP & 4,424 &, 000 \\
\hline
\end{tabular}

a. Dependent

Variabel: $Y$

Sumber:

Output SPSS

Data

Bedasarkan hasil tabel diatas dapat disimpulkan bahwa uji hipotesis yang pertama yaitu:

H1 : Sistem Informasi Akuntansi Berpengaruh Terhadap Efektivitas Pengendalian Internal Penjualan

Penelitian ini dapat membuktikan bahwa adanya pengaruh sistem informasi akuntansi terhadap efektivitas pengendalian internal penjualan. Hal ini menunjukan bahwa nilai signifikansi $<0,05$ yaitu 0,010 dan nilai thitung $>$ tabel yaitu 2,671 >0,6784. Hasil ini dikarenakan adanya komponen-komponen sistem informasi yang sangat berperan penting dalam perusahaan CV. Kurnia Agung, dimana memiliki sumber daya manusia yang kompeten dan berkualitas yang akan menciptakan efisiensi dan efektivitas dalam kelangsungan proses penjualan sehingga tugas dan kewajibannya akan terselesaikan tepat waktu dan terhindar dari kesalahan-kesalahan yang mengakibatkan kerugian perusahaan serta dengan adanya alat yang canggih akan mendukung kinerja para karyawan sehingga proses penjualan berjalan dengan efektif dan efisiensi.

H2 : Lingkungan Pengendalian Berpengaruh Terhadap Efektivitas Pengendalian Internal Penjualan

\begin{tabular}{|ll|l|l|}
\hline \multicolumn{2}{|l|}{ Model } & \multicolumn{2}{|l|}{$\begin{array}{l}\text { Unstandardized } \\
\text { Coefficients }\end{array}$} \\
\cline { 2 - 4 } & B & Std. Error \\
\hline \multirow{4}{*}{$\begin{array}{l}\text { (Consta } \\
\text { nt) }\end{array}$} &, 794 &, 424 \\
& SIA &, 307 &, 115 \\
& LP &, 506 &, 114 \\
\hline \multicolumn{3}{|c|}{ Penelitian ini dapat }
\end{tabular}

membuktikan bahwa adanya pengaruh lingkungan pengendalian terhadap efektivitas pengendalian. Hal ini 
menunjukan bahwa hasil uji statistik t adalah nilai signifikansi $<0,05$ yaitu 0,000 dan nilai thitung $>$ tabel yaitu 4,424 $>0,6784$. Hal ini dikarenakan adanya komponen-komponen dari lingkungan pengendalian yang berperan dalam proses bisnis CV. Kurnia Agung, dimana suatu struktur organisasi yang dibuat perusahaan telah mendukung. Hal ini juga didukung dengan adanya komunikasi di dalam perusahaan yang akan mengurangi suatu kesalahpahaman dan akan membantu mengefisienkan waktu selama kelangsungan proses penjualan.

Kemudian pengujian hipotesis dala penelitian ini menggunakan uji $F$ yang pada dasarnya menunjukan apakah semua variabel independen yang dimasukan dalam model mempunyai pengaruh secara bersama-sama terhadap variabel dependen. Hasil pengujian pada penelitian ini dapat dilihat pada tabel dibawah ini:

Tabel 12: Hasil Uji Statistik F

ANOVA $^{a}$

\begin{tabular}{|r|l|l|l|l|l|}
\hline Model & $\begin{array}{l}\text { Sum } \\
\text { of } \\
\text { Squar } \\
\text { es }\end{array}$ & df & $\begin{array}{l}\text { Mean } \\
\text { Squa } \\
\text { re }\end{array}$ & $\mathrm{F}$ & Sig \\
\hline $\begin{array}{l}\text { Regr } \\
\text { essio } \\
\mathrm{n}\end{array}$ & 3,294 & 2 & 1,647 & 35, &, 00 \\
$1 \begin{array}{l}\text { Resi } \\
\text { dual } \\
\text { Total }\end{array}$ & 2,870 & 62 & 645 & $0^{\mathrm{b}}$ \\
\hline
\end{tabular}

a. Dependent Variable: EP

b. Predictors: (Constant), LP, SIA

Sumber: Data Output SPSS

Berdasarkan tabel diatas dapat disimpulkan bahwa uji hipotesis ke tiga diterima.

H3 : Sistem Informasi Akuntansi Dan Lingkungan Pengendalian Berpengaruh Secara Simultan
Terhadap Efektivitas Pengendalian Internal Penjualan

Pada hasil penelitian ini menunjukan bahwa adanya pengaruh sistem informasi akuntansi dan lingkungan pengendalian terhadap efektivitas pengendalian internal penjualan. Hal ini dapat dibuktikan berdasarkan uji statistik $\mathrm{F}$ menunjukan hasil nilai signifikansi $0,000<0,005$ dan nilai $F_{\text {hitung }}>F_{\text {tabel }}$ yaitu $35,575>$ 3,14 . Artinya sistem informasi akuntansi dan lingkungan pengendalian berpengaruh secara simultan terhadap efektivitas pengendalian internal penjualan. Jika sistem informasi akuntansi dan lingkungan pengendalian semakin baik maka efektivitas pengendalian internal penjualan akan semakin meningkat. Karena kedua variabel ini sangat mempengaruhi efektivitas pengendalian internal penjualan, dimana seluruh komponen dari sistem informasi akuntansi terutama pada komponen sumber daya manusia sangat kompeten dan alat yang digunakan telah memadai untuk proses penjualan pada CV. Kurnia Agung dan lingkungan pengendalian pun berperan penting dalam proses penjualan pada CV. Kurnia Agung, karena struktur organisasi pada perusahaan telah baik dan berjalan sesuai tugasnya masing-masing.

Selanjuatnya dalam uji koefisien determinasi ini dilakukan untuk mengukur seberapa jauh kemampuan variabel independen $\left(\mathrm{X}_{1}, \mathrm{X}_{2}\right)$ dalam menerangkan variasi variabel dependen $(Y)$. Nilai koefisien adalah antara 0 dan 1 . Uji koefisien determinasi dapat dilihat pada tabel dibawah ini:

Tabel 4.17

Hasil Uji Koefisien Determinasi $\left(\mathbf{R}^{2}\right)$ 
Model Summary ${ }^{b}$

\begin{tabular}{|l|l|l|l|l|}
\hline Model & $R$ & $\begin{array}{l}\text { R } \\
\text { Squ } \\
\text { are }\end{array}$ & $\begin{array}{l}\text { Adjus } \\
\text { ted R } \\
\text { Squar } \\
\mathrm{e}\end{array}$ & $\begin{array}{l}\text { Std. Error } \\
\text { of the } \\
\text { Estimate }\end{array}$ \\
\hline 1 & $\begin{array}{l}, 731 \\
\mathrm{a}\end{array}$ &, 534 &, 519 &, 21517 \\
\hline
\end{tabular}

a. Predictors: (Constant), LP, SIA

b. Dependent Variable: EP

\section{Sumber: Data Output SPSS}

Pada tabel diatas menunjukan hasil bahwa koefisien determinasi (Adjusted $R$ Square) adalah 0,519 atau 51,9\% yang artinya bahwa efektivitas pengendalian internal penjualan dipengaruhi oleh sistem informasi akuntansi dan lingkungan pengendalian sebesar $51,9 \%$ dan 48,9 $\%$ di pengaruhi oleh faktor-faktor lain yang tidak diteliti seperti kinerja karyawan, audit intern.

\section{KESIMPULAN DAN SARAN}

\section{Kesimpulan}

Berdasarkan hasil pengujian

hipotesis dan mengacu pada identifikasi

masalah penelitian ini, dapat ditarik

kesimpulan-kesimpulan sebagai berikut:

1. Penerapan sistem informasi akuntansi pada CV. Kurnia Agung sudah baik, hal ini dapat dilihat pada seluruh komponen sistem informasi akuntansi yang berperan penting dalam kelangsungan proses penjualan pada CV. Kurnia Agung terutama pada sumber daya manusia yang dimiliki perusahaan sudah kompeten dan berkualitas yang dapat meningkatkan efisiensi dan efektivitas dalam perusahaan.

2. Lingkungan pengendalian yang terdapat di CV. Kurnia Agung sudah baik, hal ini dapat dilihat pada seluruh unsur-unsur lingkungan pengendalian berperan dalam kelangsungan proses penjualan pada CV. Kurnia Agung dimana struktur organisasi yang dibentuk perusahaan telah disusun dengan baik dan dengan adanya komunikasi antar karyawan akan mengurangi kesalahan-kesalahan yang akan mengakibatkan kerugian pada perusahaan.

3. Secara simultan sistem informasi akuntansi dan lingkungan pengendalian berpengaruh terhadap efektivitas pengendalian internal penjualan pada CV. Kurnia Agung. Hal ini dikarenakan sistem informasi akuntansi yang digunakan CV. Kurnia Agung telah efektif dengan adanya sumber daya manusia dan alat yang berkualitas yang akan meningkatkan efisiensi dan efektivitas perusahaan, dan lingkungan pengendalian pada CV. Kurnia Agung telah efektif dengan adanya struktur organisasi yang telah disusun dengan benar.

\section{Saran}

Berdasarkan kesimpulan diatas, maka dapat beberapa saran dari hasil penelitian yang diperoleh, yaitu:

1. Untuk CV. Kurnia Agung harus tetap meningkatkan sistem informasi akuntansi yang digunakan dengan cara mengupdate sistem yang digunakan dalam proses penjualan agar informasi yang di peroleh semakin tepat dan akurat, melakukan pelatihan untuk pengguna sistem informasi akuntansi agar dapat menyelesaikan tugas-tugas dan kewajibannya tepat waktu dan terhindar dari kesalahan-kesalahan yang akan merugikan perusahaan. Mengingat variabel lingkungan pengendalian juga berpengaruh terhadap efektivitas pengendalian maka CV. Kurnia Agung diharapkan untuk menjaga dan meningkatkan lingkungan pengendalain dengan cara memperkuat struktur organisasi dan komunikasi antar karyawan yang 
berkaitan agar tidak terjadi kesalahpahaman yang akan mengganggu proses penjualan.

2. Untuk penelitian selanjutnya diharapkan agar memperluas sampel yang akan digunakan tidak hanya pada 7 tempat, dan di harapkan untuk menambah variabel independen yang lain yang dapat mempengaruhi efektivitas pengendalian internal penjualan seperti kinerja karyawan

\section{DAFTAR PUSTAKA}

\section{Buku}

A. Hall. James. 2011. Sistem Informasi Akuntansi. Buku 1 Edisi 4. Jakarta: Salemba Empat.

Azhar Susanto. 2013. Sistem Informasi Akuntansi. Edisi Pertama. Bandung: Lingga Jaya.

Arikunto, Suharsimi. 2006. Metedologi Penelitian. Yogyakarta: Bina Aksara

A. Romney, Marshall \& John Steinbart Paul. 2014. Accounting Information Systems, Edisi 13. Jakarta: Salemba Empat.

Krismiaji. 2015. Sistem Informasi Akuntansi. Edisi 4. Yogyakarta: UPP STIM YKPN.

Ritonga, Rahman. 1997. Statistik Untuk Penelitian Psikologi dan Penelitian. Jakarta: Lembaga Penerbit Fakultas Ekonomi UI.

Sugiyono. 2003. Metode Penelitian Bisnis. Bandung: Pusat Bahasa Depdiknas.

Sugiyono. 2013. Metode Penelitian Kuantitatif, Kualitatif Dan R\&D. Bandung: CV. Alfabeta.
Sujawerni, V Wiratna. 2014. Metodelogi Penelitian. Yogyakarta: Pustakabarupress.

Sujawerni, V Wiratna. 2015. Sistem Akuntansi. Yogyakarta: Pustakabarupress.

\section{Jurnal dan Skripsi}

Citramurti, Apsari. 2012. Penerapan Sistem Informasi Akuntansi Dalam Efektivitas Pelaksanaan Pengendalian Intern Penjualan Jasa Perawatan Pipa Migas Pada PT. Tonsco International.

Kurniawan. 2016. Pengaruh Sistem Informasi Akuntansi Penjualan Terhadap Efektivitas Pengendalian Internal Penjualan Pada PT. Niaga Swadaya Makassar.

Kurniawati. Heny. 2011. Evaluasi Lingkungan Pengendalian Dalam Petumbuhan Usaha Yang Cepat: Studi Kasus Pada PT G. Binus Business Review Vol.2 No.1 ISSN: 456-465.

Rahayu, Peni Fibro. 2014. Pengaruh Sistem Informasi Akuntansi dan Ketetapan Pembayaran Piutang Terhadap Pengendalian Internal Penjualan. Jurnal Ilmu \& Riset Akuntansi Vol.3 No.4.

Salam, Alizah Zulkhaidah dan Hiro Tugiman. 2017. Analisis Unsur Lingkungan Pengendalian Pada Sistem Pengendalian Intern Pemerintah (SPIP) Di Kabupaten Takalar. ISSN: 2355-9375.

\section{Website}

http://id.wikipedia.org/wiki/Pengendalian_inte $\underline{\text { rn }}$

http://theorymethod.blogspot.co.id/2015/12/uj i-goodness-of-fit-uji.html 
http://www.dosenpendidikan.com/pengertianvariabel-beserta-macam-macamnya-menurutpara-ahli/

http://www.ilmu-

ekonomi.com/2011/11/komponen-

Pengendalian-intern.html 